Pacific Northwest

National Laboratory

Operated by Battelle for the

U.S. Department of Energy

\section{Assessment of Unabated Facility Emission Potentials for Evaluating Airborne Radionuclide Monitoring Requirements at Pacific Northwest National Laboratory - 2003}

\author{
M. Y. Ballinger \\ T. L. Gervais \\ M. J. Sula \\ D. L. Edwards
}




\title{
DISCLAIMER
}

This report was prepared as an account of work sponsored by an agency of the United States Government. Neither the United States Government nor any agency thereof, nor Battelle Memorial Institute, nor any of their employees, makes any warranty, express or implied, or assumes any legal liability or responsibility for the accuracy, completeness, or usefulness of any information, apparatus, product, or process disclosed, or represents that its use would not infringe privately owned rights. Reference herein to any specific commercial product, process, or service by trade name, trademark, manufacturer, or otherwise does not necessarily constitute or imply its endorsement, recommendation, or favoring by the United States Government or any agency thereof, or Battelle Memorial Institute. The views and opinions of authors expressed herein do not necessarily state or reflect those of the United States Government or any agency thereof.

\author{
PACIFIC NORTHWEST NATIONAL LABORATORY \\ operated by \\ BATTELLE \\ for the \\ UNITED STATES DEPARTMENT OF ENERGY \\ under Contract DE-ACO6-76RLO183O
}

Printed in the United States of America

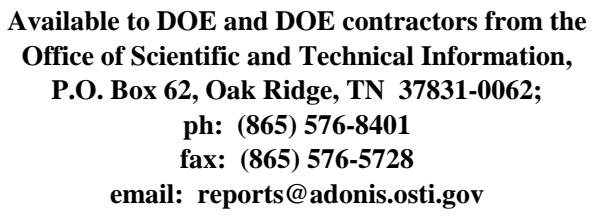

email: reports@adonis.osti.gov

\author{
Available to the public from the National Technical Information Service, \\ U.S. Department of Commerce, 5285 Port Royal Rd., Springfield, VA 22161 \\ ph: (800) 553-6847 \\ fax: (703) 605-6900 \\ email: orders@ntis.fedworld.gov \\ online ordering: http://www.ntis.gov/ordering.htm
}


PNNL-10855, Rev. 3

\title{
Assessment of Unabated Facility Emission Potentials for Evaluating Airborne Radionuclide Monitoring Requirements at Pacific Northwest National Laboratory - 2003
}

\author{
M. Y. Ballinger \\ M. J. Sula \\ T. L. Gervais \\ D. L. Edwards
}

December 2003

Prepared for the U.S. Department of Energy under Contract DE-AC06-76RL01830

Pacific Northwest National Laboratory

Richland, Washington 99352 


\begin{abstract}
Assessments were performed to evaluate compliance with the airborne radionuclide emission monitoring requirements in the National Emission Standards for Hazardous Air Pollutants (NESHAP - U.S. Code of Federal Regulations, Title 40, Part 61, Subpart H) and Washington Administrative Code (WAC) 246-247: Radiation Protection - Air Emissions. In these assessments, potential unabated offsite doses were evaluated for emission locations at facilities owned by the U.S. Department of Energy and operated by Pacific Northwest National Laboratory (PNNL) on the Hanford Site. This report describes the inventory-based methods and provides the results for the assessment performed in 2003.
\end{abstract}





\section{Summary}

Assessments were performed to evaluate compliance with the airborne radionuclide emission monitoring requirements in the National Emission Standards for Hazardous Air Pollutants (NESHAP - U.S. Code of Federal Regulations, Title 40 Part 61, Subpart H). In these assessments, potential unabated offsite doses were evaluated for emission locations at facilities owned by the U.S. Department of Energy and operated by Pacific Northwest National Laboratory (PNNL) on the Hanford Site. One of the facilities evaluated, the 325 Building Radiochemical Processing Laboratory, met state and federal criteria for continuous sampling of airborne radionuclide emissions. The 331 Building Life Sciences Laboratory was recognized as having a mission with the potential for meeting the continuous sampling criteria. The 3720 Environmental Sciences Laboratory was also recognized as having a mission with the potential for meeting the continuous sampling criteria, but was undergoing a transition to shut-down status.

The assessments were performed using building radionuclide inventory data obtained in 2003. The list of buildings evaluated is provided in Table S.1.

Table S.1. PNNL-Operated DOE Buildings with Radioactive Inventories in 2003

200E Prototype Surface Barrier Storage

306-W Materials Development Building

318 Radiological Calibrations Laboratory

320 Analytical and Nuclear Research Laboratory

323 Mechanical Properties Laboratory

325 Radiochemical Processing Laboratory

326 Materials Sciences Laboratory

329 Chemical Sciences Laboratory

331 Life Sciences Laboratory I

331-G Interim Tissue Repository

331-H Aerosol Wind Tunnel Research Facility

337 Technical Management Center

338 Prototype Engineering Laboratory

747A Whole Body Counter

3020 Environmental Molecular Sciences Laboratory

3720 Environmental Sciences Laboratory

3730 Gamma Irradiation Facility 


\section{Glossary}

$\begin{array}{ll}\text { AMD } & \text { Aerodynamic Mean Diameter } \\ \text { ANSI } & \text { American National Standards Institute } \\ \text { CAP88PC } & \text { Clean Air Act Assessment Package -1988 for Personal Computers } \\ \text { CFR } & \text { Code of Federal Regulations } \\ \text { DOE } & \text { Department of Energy } \\ \text { DOT } & \text { Department of Transportation } \\ \text { EM } & \text { Effluent Management } \\ \text { EMSL } & \text { Environmental Molecular Sciences Laboratory } \\ \text { EPA } & \text { Environmental Protection Agency } \\ \text { MBA } & \text { Material Balance Area } \\ \text { NESHAP } & \text { National Emission Standards for Hazardous Air Pollutants } \\ \text { PNNL } & \text { Pacific Northwest National Laboratory } \\ \text { PTE } & \text { Potential-to-Emit } \\ \text { WAC } & \text { Washington Administrative Code }\end{array}$




\section{Contents}

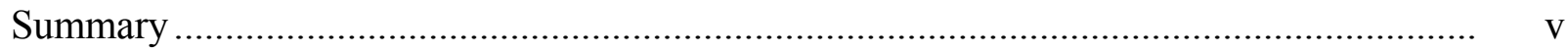

Glossary

vi

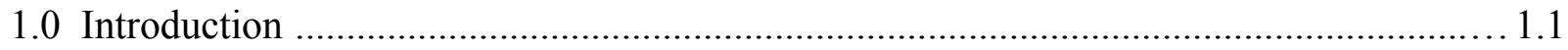

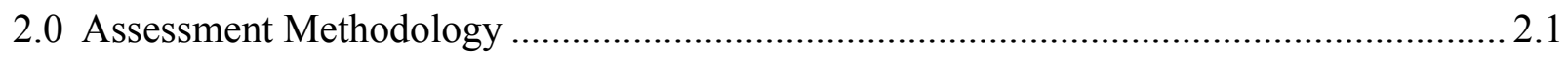

2.1 Projections of Annual Emission Quantities ............................................................. 2.1

2.2 Maximum Receptor Unit Dose Calculation ............................................................ 2.4

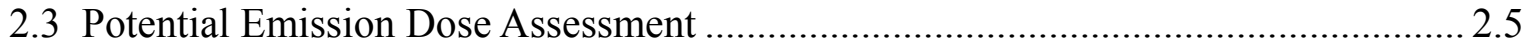

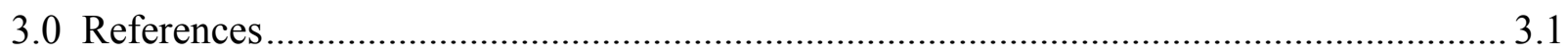

Appendix A - Common Radionuclide Mixtures …………..........................................................

Appendix B - Radionuclide Inventory Database Features......................................................... 1

\section{Tables}

S.1 PNNL-Operated DOE Buildings with Radioactive Inventories in 2003 ......................... iii

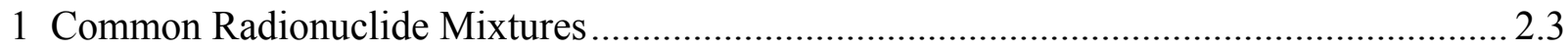

2 Physical Forms and Potential Annual Release Fractions for Radionuclides ........................ 2.4

3 Emission System Potential Dose Assessment Summary ……........................................... 2.6 


\subsection{Introduction}

Requirements for sampling airborne radionuclide emissions are contained in the following regulations and guides:

- U.S. Code of Federal Regulations (CFR), Title 40, Subpart H: National Emission Standards for Emissions of Radionuclides Other Than Radon From Department of Energy Facilities (2002)

- Washington Administrative Code (WAC) 246-247: Radiation Protection - Air Emissions (1994)

- U.S. Department of Energy, DOE/EH-0173T, Environmental Regulatory Guide for Radiological Effluent Monitoring and Environmental Surveillance (January 1991).

These documents require the performance of continuous sampling at emission points that have the potential to cause an offsite dose of $0.1 \mathrm{mrem} / \mathrm{yr}$, if routine emissions were not mitigated by engineered pollution control systems.

In response to these requirements, the potential unmitigated offsite receptor dose from the facilities, operated for the U.S. Department of Energy (DOE) by Pacific Northwest National Laboratory ${ }^{1}$ (PNNL) and containing radioactive materials or sources, is evaluated annually. These evaluations were performed initially in 1991 for the PNNL facilities on the Hanford Site. Based on the initial assessments, four PNNL buildings were identified as containing a sufficient inventory of radioactive material that unmitigated emissions could potentially result in an annual offsite maximum receptor dose of $0.1 \mathrm{mrem}$. These buildings were the 324 Waste Technology Engineering Laboratory, the 325 Radiochemical Processing Laboratory, the 327 Postirradiation Testing Laboratory, and the 3720 Environmental Sciences Laboratory. In accordance with the National Emission Standard for Hazardous Air Pollutants (NESHAP), qualifying emission points from these buildings were sampled continuously.

The original radionuclide assessments were updated annually. No changes were made in the facility emission NESHAP status until 1996 when the 324 and 327 Buildings were transitioned to other Hanford Site contractors. In 1997, proposed movement of the radionuclide inventory from the 3720 Building to the 331 Building upgraded the 331 Building to major stack status. The move was accomplished in 1998 and 1999. With disposal of some materials, the 3720 and the 331 Buildings' Potential-To-Emit (PTE) ${ }^{2}$ dropped to less than 0.1 mrem. The major stack for 3720 will be de-registered in the future when the building has completed transition activities and is inactive. However, the continued mission in the 331 Building supports a permitted PTE of $>0.1 \mathrm{mrem} / \mathrm{yr}$. Thus, the 331 Building main stack is maintained as a major stack and

${ }^{1}$ Operated by Battelle for the U.S. Department of Energy under Contract DE-AC0676RL01830.

2 Potential-to-Emit is defined as the rate of release of radionuclides from an emission unit based on the actual or potential discharge of the effluent stream that would result if all abatement control equipment did not exist, but operations are otherwise normal. 
continuously sampled. Results of the 1992-1993 assessment were documented by Sula and Jette (1994) with updates in 1995, 1999, and 2001. This report documents the most recent methods and assessments for 2003. 


\subsection{Assessment Methodology}

This section describes the methods used by PNNL to determine the potential emissions of radioactive materials from facilities DOE-owned facilities operated by PNNL.

\subsection{Projections of Annual Emission Quantities}

Several methods for projecting potential unmitigated annual emission quantities are prescribed in WAC 246-247:

- apply an annual release fraction to the radionuclide inventory in the facility

- multiply actual measured annual emissions by control system decontamination factors

- add actual measured annual emission quantities to actual measured quantities retained by control systems

- measure the annual discharge upstream from all control devices.

The inventory-based assessment method ${ }^{1}$ has been used by PNNL since the initial facility assessment in 1991. The inventory method yields an assessment based on the current building status (or even the future status if projected future inventory quantities are used in the assessment), while the other prescribed methods yield an assessment based on past facility measurements. The inventory method may be more appropriate for use at research and development facilities where types and quantities of radionuclides may change from year-to-year and where historical sampling data may not be a reliable predictor of future emissions.

At PNNL, radioactive source and material information is maintained using several separate inventory systems, as follows:

Nuclear Materials Inventory. This inventory includes most of the tritium, uranium, and transuranics in PNNL facilities. The inventory includes material in process, as well as residual contamination from historical operations in the facility. The Nuclear Materials Inventory is categorized as Type 3 inventory. The Type designation is used by PNNL to identify the source of inventory data.

${ }^{1}$ This method is described in WAC $246-247$ as follows: Multiply the annual possession quantity of each radionuclide by the release fraction for that radionuclide, depending on its physical state. Use the following release fractions: (i) 1 for gases, (ii) $10^{-3}$ for liquids or particulate solids, and (iii) $10^{-6}$ for solids. Determine the physical state for each radionuclide by considering its chemical form and the highest temperature to which it is subjected. Use a release fraction of 1 if the radionuclide is subjected to temperatures at or above its boiling point; use a release fraction of $10^{-3}$ if the radionuclide is subjected to temperatures at or above its melting point but below its boiling point. If the chemical form is not known, use a release fraction of 1 for any radionuclide that is heated to a temperature of one hundred degrees Celsius or more, boils at a temperature of one hundred degrees Celsius or less, or is intentionally dispersed into the environment. 
Composite Radioactive Materials Inventory. This inventory includes DOE-owned radioactive sources above specific de minimus values or those values that need to be considered based on the December 1998 revision to 10 CFR 835 and all radioactive material that is possessed by PNNL under their State of Washington Radioactive Materials License. Most of the radionuclides in this inventory are in sealed source form. The Composite Radioactive Materials Inventory is categorized as Type 2 inventory.

Facilities Management Radioactive Materials Inventory. This database was developed specifically to account for all radioactive material not included in either the Type 2 or Type 3 inventories. This category consists primarily of fission product radionuclides, including radionuclides in process, as well as known residual contamination from historical operations in the facility. Activation products are also included in this inventory. The Facilities Management Radioactive Material Inventory is categorized as Type 1 inventory.

The PNNL Effluent Management Group annually requests Type 1 inventory information from the custodians of the radioactive inventory. This request is made through a central point of contact for each of the PNNL divisions who then requests inventory information from custodians in his/her organization. The Effluent Management Group also requests Type 2 and Type 3 inventories from the custodians of the Composite Radioactive Materials Inventory and Nuclear Materials Inventory databases, respectively.

While the type of information contained in each of the systems varies, the overall process remains the same. After compiling the information and reformatting it, radioactive materials are identified by type, physical form, and quantity. Quantities are expressed either in terms of activity (Ci) or mass (grams). Radioactive material types may be expressed as specific radionuclides or as standard mixtures of radionuclides. For example, mixed radionuclides may be expressed as natural uranium, depleted uranium, or $6 \%\left({ }^{240} \mathrm{Pu}\right)$ plutonium, as shown in Table 1. Appendix A provides the basis for these values. Individual radionuclides or mixtures of radionuclides in small quantities may also be reported as alpha or beta activity for simplification. These materials are assumed to be ${ }^{241} \mathrm{Am}$ (alpha) or ${ }^{137} \mathrm{Cs}$ (beta) for dose assessment purposes because these two radioactive materials are some of the highest dose contributors commonly found in PNNL facilities. 
Table 1. Common Radionuclide Mixtures

\begin{tabular}{|c|c|}
\hline Material & $\begin{array}{c}\text { Specific Activity } \\
\text { (Ci alpha/g) }\end{array}$ \\
\hline Depleted Uranium & $3.6 \mathrm{E}-07$ \\
\hline Natural Uranium & $6.9 \mathrm{E}-07$ \\
\hline Hanford Uranium & $9.0 \mathrm{E}-7$ \\
\hline U-enriched $\left(<20 \%{ }^{235} \mathrm{U}\right)$ & $9.4 \mathrm{E}-06$ \\
\hline U-enriched $\left(<90 \%{ }^{235} \mathrm{U}\right)$ & $6.2 \mathrm{E}-05$ \\
\hline $\mathrm{Pu}\left(6 \%{ }^{240} \mathrm{Pu}\right)$ & 0.10 \\
\hline $\mathrm{Pu}\left(12 \%{ }^{240} \mathrm{Pu}\right)$ & 0.19 \\
\hline $\mathrm{Pu}\left(24 \%{ }^{240} \mathrm{Pu}\right)$ & 0.79 \\
\hline
\end{tabular}

Radionuclides meeting any of the following criteria are excluded from the assessments:

- radionuclides present in commercially available building/construction materials

- radionuclides that can be purchased or possessed without a special radioactive materials license

Inventory data is entered into a database that was developed specifically for these calculations. Appendix B provides a summary of the database features. The data are reviewed and revised, as needed, to eliminate duplicates, provide consistency in nuclide and unit identifications, and obtain additional information as required by the calculations. The review process is documented and filed with the assessment records.

Potential release fractions for radionuclides are based on the physical form of the radionuclide as shown in Table 2. Radionuclides present as sealed sources or in sealed, unvented Department of Transportation (DOT) shipping containers are assumed to be unavailable for release under normal circumstances. 
Table 2. Physical Forms and Potential Annual Release Fractions for Radionuclides

\begin{tabular}{|c|c|l|c|}
\hline Form & Code & \multicolumn{1}{|c|}{ Description } & $\begin{array}{c}\text { Potential } \\
\text { Release } \\
\text { Fraction }\end{array}$ \\
\hline Gas & G & $\begin{array}{l}\text { Nuclide will exceed its boiling point when } \\
\text { uncontained; exception - nuclides in gaseous } \\
\text { form in unopened commercial gas cylinders } \\
\text { may be listed as L. }\end{array}$ & 1 \\
\hline Liquid/Powder & L/P & $\begin{array}{l}\text { Nuclide will exceed its melting point or be } \\
\text { present in particulate form (Aerodynamic Mean } \\
\text { Diameter [AMD] }<100 \text { microns) when } \\
\text { uncontained; exception - liquid and powders in } \\
\text { unopened containers may be listed as S. }\end{array}$ & $10^{-3}$ \\
\hline Solid & $\mathrm{S}$ & $\begin{array}{l}\text { Nuclides not meeting conditions for the more } \\
\text { dispersible classes. }\end{array}$ & $10^{-6}$ \\
\hline Contained & $\mathrm{C}$ & $\begin{array}{l}\text { Sealed sources or material in sealed, DOT } \\
\text { containers, except those meeting exempt } \\
\text { criteria. }\end{array}$ & 0 \\
\hline Exempt & $\mathrm{E}$ & $\begin{array}{l}\text { Sealed sources that may be excluded from } \\
\text { Facility Hazard Categorization according to } \\
\text { DOE-STD-1027-92. }\end{array}$ & 0 \\
\hline
\end{tabular}

(a) American National Standards Institute

\subsection{Maximum Receptor Unit Dose Calculation}

For unit dose calculations, the maximum offsite receptor is defined as an individual whose residence location, work location, and lifestyle maximize the dose from airborne pathways. All potential environmental transport pathways associated with an airborne radionuclide release were included (that is, air inhalation, air submersion, exposure to deposited radionuclides, uptake of vegetation grown in contaminated soil).

Unit dose factors for the maximum offsite receptor were calculated for specific radionuclides using the EPA compliance code CAP88-PC (Parks 1992). Radionuclides that were not represented in CAP88-PC were conservatively assigned default values, usually equal to that of ${ }^{241} \mathrm{Am}$ for alpha emitters or ${ }^{137} \mathrm{Cs}$ for non-alpha emitters. The decay of the daughter products was also considered in assigning default values for short half-life radionuclides. The unit dose factor calculations were performed for the Hanford Site and documented (Rokkan, Rhoads, and Staven 2002). This document describes the methods and assumptions used and provides unit

${ }^{1}$ Inventory data is also used to confirm Hazard Category assignments for PNNL facilities. 
dose factors for the 300 Area.

For the Environmental Molecular Sciences Laboratory (EMSL), dose assessments were performed by applying a location correction factor to the 300 Area unit dose factor to correct for varying source-receptor distances and directions. The location correction factor was calculated by dividing the atmospheric dispersion values (Chi/Q) for these buildings by the atmospheric dispersion values for the 300 Area. The code CAP88-PC was used to calculate these dispersion values. Similar calculations were performed to obtain location correction factors for other PNNL-operated DOE facilities outside the 300 Area.

\subsection{Potential Emission Dose Assessment}

Doses from projected radionuclide emissions were calculated by multiplying the quantity of each radionuclide present in the facility by its associated potential release fraction, the 300 Area unit dose factor, and the location correction factor. Doses from individual radionuclides were summed to derive the total potential unabated annual emission dose for each facility.

The assessments were independently reviewed. Then, packets were prepared for each building containing the raw inventory information, any communications clarifying or correcting the inventory information, summarized inventory information, and a cover sheet showing the resulting dose and approval signatures. The packets were approved by the preparer, the reviewer, the divisional points of contact for the inventory custodians, and the building managers. After approval, assessment packets are maintained as records by the Effluent Management Group. A summary of the assessment results for 2003 is provided in Table 3. The table also identifies the radionuclides in inventory that contribute $10 \%$ or more of the potential dose for facilities where continuous sampling is required. 
Table 3. Emission System Potential Dose Assessment Summary

\begin{tabular}{|c|c|c|c|c|c|}
\hline $\begin{array}{l}\text { Emission } \\
\text { System }\end{array}$ & $\begin{array}{l}\text { Emission } \\
\text { Type }^{1}\end{array}$ & System Description & $\begin{array}{l}\text { Emission } \\
\text { Measurement } \\
\text { Required }\end{array}$ & $\begin{array}{l}\text { Nuclides } \\
\text { Contributing }> \\
10 \% \text { of Potential } \\
\text { Dose }\end{array}$ & Comment \\
\hline \multicolumn{6}{|c|}{ Systems Located in the Southeast Region (300 Area) of the Hanford Site } \\
\hline $306-\mathrm{W}$ & Point & $\begin{array}{l}\text { Materials Development } \\
\text { Building }\end{array}$ & Confirmatory & & \\
\hline 318 & Point & $\begin{array}{l}\text { Radiological Calibrations } \\
\text { Laboratory }\end{array}$ & Confirmatory & & $\begin{array}{l}\text { Primarily } \\
\text { sealed sources }\end{array}$ \\
\hline 320 & Point & $\begin{array}{l}\text { Analytical and Nuclear } \\
\text { Research Laboratory }\end{array}$ & Confirmatory & & \\
\hline 323 & Point & $\begin{array}{l}\text { Mechanical Properties } \\
\text { Laboratory }\end{array}$ & Confirmatory & & \\
\hline 325 & Point & $\begin{array}{l}\text { Radiochemical Processing } \\
\text { Laboratory }\end{array}$ & Continuous & $\begin{array}{l}\mathrm{Am}-241, \mathrm{H}-3, \mathrm{Pu}- \\
238, \mathrm{Pu}-239\end{array}$ & \\
\hline 326 & Point & $\begin{array}{l}\text { Materials Sciences } \\
\text { Laboratory }\end{array}$ & Confirmatory & & \\
\hline 329 & Point & $\begin{array}{l}\text { Chemical Sciences } \\
\text { Laboratory }\end{array}$ & Confirmatory & & \\
\hline 331 & Point & Life Sciences Laboratory I & $\begin{array}{l}\text { Continuous (Based } \\
\text { on mission) }\end{array}$ & $\begin{array}{l}\text { Np-237, Pu-239, } \\
\text { Pu-240 }\end{array}$ & \\
\hline $331 \mathrm{G}$ & Point & Interim Tissue Repository & None & None & $\begin{array}{l}\text { Sealed } \\
\text { Sources Only }\end{array}$ \\
\hline $331 \mathrm{H}$ & Point & $\begin{array}{l}\text { Aerosol Wind Tunnel } \\
\text { Research Facility }\end{array}$ & None & None & $\begin{array}{l}\text { Sealed } \\
\text { Sources Only } \\
\end{array}$ \\
\hline 337 & Fugitive & $\begin{array}{l}\text { Technical Management } \\
\text { Center }\end{array}$ & None & None & $\begin{array}{l}\text { Sealed } \\
\text { Sources (for } \\
\text { Training } \\
\text { Purposes } \\
\text { Only) } \\
\end{array}$ \\
\hline 338 & Fugitive & & None & None & $\begin{array}{l}\text { Sealed } \\
\text { Sources Only }\end{array}$ \\
\hline 3720 & Point & $\begin{array}{l}\text { Environmental Sciences } \\
\text { Laboratory }\end{array}$ & $\begin{array}{l}\text { Continuous (Based } \\
\text { on mission) }\end{array}$ & $\begin{array}{l}\text { Am-241, Cs-137, } \\
\text { Pu-239 }\end{array}$ & \\
\hline 3730 & Point & Gamma Irradiation Facility & Confirmatory & & \\
\hline $\begin{array}{l}3020 \\
\text { EMSL }\end{array}$ & Point & $\begin{array}{l}\text { Environmental Molecular } \\
\text { Sciences Laboratory }\end{array}$ & Confirmatory & & $\begin{array}{l}\text { Primarily } \\
\text { Sealed } \\
\text { Sources } \\
\end{array}$ \\
\hline \multicolumn{6}{|c|}{ Systems Located in the Central Region (200 Areas) of the Hanford Site } \\
\hline $200 \mathrm{E}$ & Fugitive & $\begin{array}{l}\text { Prototype Surface Barrier } \\
\text { Storage }\end{array}$ & None & None & $\begin{array}{l}\text { Sealed } \\
\text { Sources Only }\end{array}$ \\
\hline \multicolumn{6}{|c|}{ Systems Located in Richland } \\
\hline $747 \mathrm{~A}$ & Fugitive & Whole Body Counter & None & None & $\begin{array}{l}\text { Primarily } \\
\text { Sealed } \\
\text { Sources } \\
\end{array}$ \\
\hline
\end{tabular}

${ }^{a}$ Fugitive emissions are radioactive air emissions that do not and could not reasonably pass through a stack, vent, or other functionally equivalent structure, and that are not feasible to 
directly measure and quantify (WAC 1994). 


\subsection{References}

10 CFR 835. 1998. US Environmental Protection Agency, "Occupational Radiation Protection." US Code of Federal Regulations.

40 CFR 61, Subpart H. 2002. US Environmental Protection Agency, "National Emission Standards for Emissions of Radionuclides Other Than Radon From Department of Energy Facilities." US Code of Federal Regulations..

Ballinger, M. Y., S. J. Jette, and M. J. Sula. 1995. Assessment of Unabated Facility Emission Potentials for Evaluating Airborne Radionuclide Monitoring Requirements at Pacific Northwest National Laboratory - 1995. PNL-10855, Pacific Northwest Laboratory, Richland, Washington.

Ballinger, M. Y., K. D. Shields, M. J. Sula, and D. L. Edwards. 1999. Assessment of Unabated Facility Emission Potentials for Evaluating Airborne Radionuclide Monitoring Requirements at Pacific Northwest National Laboratory - 1999. PNNL-10855, Rev. 1, Pacific Northwest Laboratory, Richland, Washington.

Ballinger, M. Y., K. D. Shields, M. J. Sula, D. L. Edwards, and TL Gervais. 2001. Assessment of Unabated Facility Emission Potentials for Evaluating Airborne Radionuclide Monitoring Requirements at Pacific Northwest National Laboratory - 2001. PNNL-10855, Rev. 2, Pacific Northwest Laboratory, Richland, Washington.

Parks, B. S. 1992. User's Guide for CAP88-PC Version 1.0. 402-B-92-001, U.S. Environmental Protection Agency, Office of Radiation Programs, Las Vegas Facility, Las Vegas, Nevada.

Rokkan, D. J., K. Rhoads, and L. H. Staven. 2002. Calculating Potential-to-Emit Releases and Doses for FEMPs and NOCs. HNF-3602, Revision 1, Fluor Hanford, Richland, Washington.

Sula, M. J. and S. J. Jette. 1994. Pacific Northwest Laboratory Facilities Radionuclide Inventory Assessment CY 1992-1993. PNL-10061. Pacific Northwest Laboratory, Richland, Washington.

US Department of Energy (DOE). 1991. "Environmental Regulatory Guide for Radiological Effluent Monitoring and Environmental Surveillance.” DOE/EH-0173T.

US Department of Energy (DOE). 1992. "Hazard Categorization and Accident Analysis Techniques for Compliance with DOE Order 5480.23, Nuclear Safety Analysis Reports." DOESTD-1027-92.

Washington Administrative Code (WAC). 1994. "Radiation Protection - Air Emissions." WAC 246-247, Olympia, Washington. 


\section{Appendix A}

\section{Common Radionuclide Mixtures}

For uranium and plutonium inventory items where enrichment is known, but data on specific isotopic breakdown is not available, a method was devised to conservatively estimate potential dose. Uranium and plutonium blends can be grouped under the categories shown in Table A.1. Each of these categories represents an isotopic blend of uranium or plutonium that may be commonly found on the Hanford site. The percentages shown are weight percent and other components that make up the blend are other isotopes of uranium or plutonium. For aged plutonium blends, Am-241 also makes up a significant fraction.

Table A.1. Uranium and Plutonium Blend Information

\begin{tabular}{|l|l|l|}
\hline Material in Inventory & Blend Information & Bin \\
\hline Depleted Uranium or Uranium $\leq 0.25 \% \mathrm{U}-235$ & Depleted Uranium & $\mathrm{U}($ dep $)$ \\
\hline Natural Uranium or Uranium $\leq 0.72 \% \mathrm{U}-235$ & Natural Uranium & $\mathrm{U}($ nat $)$ \\
\hline $\begin{array}{l}\text { Uranium } \leq 0.83 \% \text { U-235 (commonly found at } \\
\text { Hanford) }\end{array}$ & Hanford Uranium & $\mathrm{U}($ Hanf) \\
\hline Uranium Enriched $\leq 20 \% \mathrm{U}-235$ & Uranium Enriched $<20 \%$ & $\mathrm{U}(20 \%)$ \\
\hline Uranium Enriched $\leq 90 \% \mathrm{U}-235$ & Uranium Enriched $<90 \%$ & $\mathrm{U}(90 \%)$ \\
\hline Uranium $\geq 90 \% \mathrm{U}-235$ & $\mathrm{U}-235$ & $\mathrm{U}-235$ \\
\hline Plutonium with $\leq 6 \% \mathrm{Pu}-240$ & $\mathrm{Pu}$ Blend with 6\% Pu-240 & $\mathrm{Pu}(6 \%)$ \\
\hline Plutonium with $\leq 12 \% \mathrm{Pu}-240$ & $\mathrm{Pu}$ Blend with $12 \% \mathrm{Pu}-240$ & $\mathrm{Pu}(12 \%)$ \\
\hline Plutonium with $\geq 12 \% \mathrm{Pu}-240$ & $\mathrm{Pu}$ Blend with $24 \% \mathrm{Pu}-240$ & $\mathrm{Pu} \mathrm{(24 \% )}$ \\
\hline
\end{tabular}

Data and calculations for each of the blends are described here. Uranium blend information was obtained from Sula, Carbaugh, and Bihl (1991) and is shown in Table A.2. The data for depleted uranium, natural uranium, and uranium commonly found at Hanford is from Tables 8.2 and 8.3 of the referenced report. For the $20 \%$ and $90 \%$ U-235 blends, an equation was used to calculate specific activity. The equation was obtained from Figure 8.1 of Sula, Carbaugh, and Bihl (1991) and is back-referenced to WASH-1251 (Alexander 1974).

$$
\mathrm{SA}=\left(0.4+0.38 \mathrm{E}+0.0034 \mathrm{E}^{2}\right)^{*} 10^{-6}
$$

Where $\mathrm{SA}=$ specific activity, $\mathrm{Ci} / \mathrm{g}$ and

$\mathrm{E}=$ weight percent of $\mathrm{U}-235$.

For $\mathrm{E}=20 \mathrm{wt} \% \mathrm{U}-235, \mathrm{~S}=9.36 \mathrm{E}-6 \mathrm{Ci} / \mathrm{g}$

For $\mathrm{E}=90 \mathrm{wt} \% \mathrm{U}-235, \mathrm{~S}=6.21 \mathrm{E}-5 \mathrm{Ci} / \mathrm{g}$

The uranium isotopes that contribute significantly to the activity are alpha emitters and have approximately the same dose potential per curie. Therefore, the specific activity is used in converting a known mass of uranium blend to activity and the activity is all attributed to U-235. 
Table A.2. Uranium Blend Specific Activities

\begin{tabular}{|c|c|}
\hline Uranium Blend & $\begin{array}{c}\text { Specific Activity, } \\
\text { Ci } / g\end{array}$ \\
\hline $\mathrm{U}(\mathrm{dep})$ & $3.64 \mathrm{E}-7$ \\
\hline $\mathrm{U}($ nat $)$ & $6.87 \mathrm{E}-7$ \\
\hline $\mathrm{U}($ Hanf $)$ & $9.0 \mathrm{E}-7$ \\
\hline $\mathrm{U}(20 \%)$ & $9.36 \mathrm{E}-6$ \\
\hline $\mathrm{U}(90 \%)$ & $6.21 \mathrm{E}-5$ \\
\hline
\end{tabular}

The radionuclide and isotopic composition of $6 \%$ and $12 \%$ plutonium blends was also obtained from Sula, Carbaugh, and Bihl (1991). Data for these Pu mixtures prior to any decay of $\mathrm{Pu}-241$ to Am-241 is shown in Table A.3 and was obtained from Tables 9.1 and 9.2 of the referenced report. Plutonium inventory items at Hanford have most likely aged for many years and contain significant amounts of Am-241. ${ }^{1}$ A 40-year age is assumed for plutonium blend calculations and the amount of $\mathrm{Pu}-241$ decayed to $\mathrm{Am}-241$ is calculated using the following equation (Shleien, Slaback, and Birky, 1998, p 3-17):

$$
\mathrm{N} / \mathrm{N}_{0}=\mathrm{e}^{(-0.693 \mathrm{t} / \mathrm{T})}
$$

Where $\mathrm{N} / \mathrm{N}_{0}=$ the fraction of parent material left,

$\mathrm{t}=$ time, and

$\mathrm{T}=1 / 2$ life of the parent material.

Pu-241 has a half-life of 14.4 years (Handbook of Health Physics and Radiological Health, Third Edition, Table 8.13) and is decayed to about $15 \%$ of its original mass after 40 years according to the equation above. Am-241 has a much longer half-life so all of the Pu-241 that is converted to Am-241 is present. Table A.3 shows the resulting weight percent of each isotope after a 40-year decay for each of the Pu blends.

Table A.3. Isotopic Composition and Specific Activity of Pu Blends

\begin{tabular}{|c|c|c|c|c|c|c|c|}
\hline \multirow{2}{*}{ Isotope } & \multirow{2}{*}{$\begin{array}{c}\text { Specific } \\
\text { Activity } \\
\mathrm{Ci} / \mathrm{g}\end{array}$} & $\begin{array}{c}\mathrm{No} \\
\mathrm{decay}\end{array}$ & $\begin{array}{c}40-\mathrm{yr} \\
\mathrm{decay}\end{array}$ & $\begin{array}{c}\text { Spec Act } \\
\text { mix }\end{array}$ & $\begin{array}{c}\text { No } \\
\text { decay }\end{array}$ & $\begin{array}{c}40-\mathrm{yr} \\
\text { decay }\end{array}$ & $\begin{array}{c}\text { Spec Act } \\
\text { mix }\end{array}$ \\
\cline { 3 - 9 } & $\mathrm{wt} \%$ & $\mathrm{wt} \%$ & $\mathrm{Ci}$ alpha/g & $\mathrm{wt} \%$ & $\mathrm{wt} \%$ & $\mathrm{Ci}$ alpha/g \\
\hline $\mathrm{Pu}-238$ & 17.1 & $0.05 \%$ & $0.05 \%$ & $8.6 \mathrm{E}-03$ & $0.1 \%$ & $0.1 \%$ & $1.7 \mathrm{E}-02$ \\
\hline $\mathrm{Pu}-239$ & 0.0621 & $93.0 \%$ & $93.0 \%$ & $5.8 \mathrm{E}-02$ & $84.4 \%$ & $84.4 \%$ & $5.2 \mathrm{E}-02$ \\
\hline $\mathrm{Pu}-240$ & 0.227 & $6.1 \%$ & $6.1 \%$ & $1.4 \mathrm{E}-02$ & $12.4 \%$ & $12.4 \%$ & $2.8 \mathrm{E}-02$ \\
\hline $\mathrm{Pu}-241$ & 103 & $0.8 \%$ & $0.1 \%$ & $(\mathrm{a})$ & $3.0 \%$ & $0.45 \%$ & (a) \\
\hline $\mathrm{Pu}-242$ & $3.92 \mathrm{E}-03$ & $0.05 \%$ & $0.05 \%$ & $2.0 \mathrm{E}-06$ & $0.1 \%$ & $0.1 \%$ & $3.9 \mathrm{E}-06$ \\
\hline Am-241 & 3.43 & $0.0 \%$ & $0.7 \%$ & $2.3 \mathrm{E}-02$ & $0.0 \%$ & $2.55 \%$ & $8.7 \mathrm{E}-02$ \\
\hline Total Mix & & & & $1.0 \mathrm{E}-01$ & & & $1.9 \mathrm{E}-01$ \\
\hline
\end{tabular}

${ }^{\text {(a) }} \mathrm{Pu}-241$ is excluded from the total mix calculation because it is a beta-emitter and the dose is

${ }^{1}$ Fuel reprocessing at Hanford took place from the mid 1940s to the mid 1980s (Ballinger and Hall 1991). 
insignificant compared to the dose from the other alpha-emitting radioactive materials. All of the isotopes in Table A.3 are alpha emitters except for $\mathrm{Pu}-241$ which decays by beta emission and is much less damaging per curie than the others. The dose effect from the Pu-241 contribution is negligible compared to the rest. Thus, $\mathrm{Pu}-241$ is excluded from further calculations and the specific activity for the mix is calculated in terms of curies of alpha emitter per gram. The specific activity of the mix is determined by summing the contributions from the alpha-emitting nuclides.

The isotopic composition for a 24\% Pu blend was obtained from ANSI N317 - 1980 Performance Criteria for Instrumentation Used for Inplant Plutonium Monitoring. This document provides isotopic compositions of plutonium for different reactor types and burnup. The composition that results in the most conservative unit dose is shown in Table A.4 and corresponds to the data for boiling water reactor with $28000 \mathrm{MWD} / \mathrm{T}$ burnup with 40 years decay for Pu-241. The data in Table A.4 was taken directly from ANSI N317 and does not quite add up to $100 \%$, most likely because of the number of significant digits used in the data.

Table A.4. Isotopic Composition and Specific Activity of $24 \% \mathrm{Pu}$ Blend

\begin{tabular}{|c|c|c|c|c|}
\hline \multirow{2}{*}{ Isotope } & \multirow{2}{*}{$\mathrm{Ci} / \mathrm{g}$} & \multicolumn{3}{|c|}{$24 \% \mathrm{Pu}$ mix } \\
\cline { 3 - 5 } & & $\mathrm{No}$ decay & $\begin{array}{c}40-\mathrm{yr} \\
\text { decay }\end{array}$ & Spec Act mix \\
\cline { 3 - 5 } & 17.1 & $1.80 \%$ & $\mathrm{wt} \%$ & $\mathrm{Ci}$ alpha/g \\
\hline $\mathrm{Pu}-238$ & 0.0621 & $54.20 \%$ & $54.2 \%$ & $3.1 \mathrm{E}-01$ \\
\hline $\mathrm{Pu}-239$ & 0.227 & $23.80 \%$ & $23.8 \%$ & $5.4 \mathrm{E}-02$ \\
\hline $\mathrm{Pu}-240$ & 103 & $13.50 \%$ & $2.0 \%$ & (a) \\
\hline $\mathrm{Pu}-241$ & $3.92 \mathrm{E}-03$ & $6.40 \%$ & $6.4 \%$ & $2.5 \mathrm{E}-04$ \\
\hline $\mathrm{Pu}-242$ & 3.43 & $0.00 \%$ & $11.5 \%$ & $3.9 \mathrm{E}-01$ \\
\hline Am-241 & & & & $7.9 \mathrm{E}-01$ \\
\hline Total Mix & & & & \\
\hline
\end{tabular}

${ }^{\text {(a) }} \mathrm{Pu}-241$ is excluded from the total mix calculation because it is a beta-emitter and the dose is insignificant compared to the dose from the other alpha-emitting radioactive materials.

The inventory assessment calculates the radiological air emission potential-to-emit (PTE) based on the inventory and unit dose factors documented in Rokkan, Rhoads, and Staven (2002). Unit doses for the 300 Area of Hanford are presented for many radionuclides for the following exposure scenarios:

- Offsite maximum public receptor, East sector of 300 Area with $<40$ m release height.

- Offsite maximum public receptor, West sector of 300 Area with $<40 \mathrm{~m}$ release height.

- Offsite maximum public receptor, East sector of 300 Area with $>40 \mathrm{~m}$ release height.

- Offsite maximum public receptor, West sector of 300 Area with $>40 \mathrm{~m}$ release height.

- Onsite maximum public receptor, $<500 \mathrm{~m}$ distance to receptor with $<40 \mathrm{~m}$ release height.

Each of these five exposure scenarios may be used for PTE calculations depending on the facility emission point and purpose of the calculation. Unit doses calculated for each of the Pu blends are provided in Table A.5 and summarized in Table A.6. 
A. 4 


\begin{tabular}{|c|c|c|c|c|c|c|c|c|c|c|c|}
\hline \multicolumn{2}{|c|}{ Isotope } & \multicolumn{2}{|c|}{ Offsite $<40 \mathrm{~m} \mathrm{E}$} & \multicolumn{2}{|c|}{ Onsite $<40 \mathrm{~m}$} & \multicolumn{2}{|c|}{ Offsite $<40 \mathrm{~m} \mathrm{~W}$} & \multicolumn{2}{|c|}{ Offsite $>40 \mathrm{~m} \mathrm{E}$} & \multicolumn{2}{|c|}{ Offsite > $40 \mathrm{~m} \mathrm{~W}$} \\
\hline 6\% Pu mix & Ci $\alpha / g$ mix & $\begin{array}{l}\mathrm{mrem} / \mathrm{C} \\
\mathrm{i}\end{array}$ & $\begin{array}{l}\text { mrem/ } \\
\mathrm{g}\end{array}$ & $\begin{array}{l}\mathrm{mrem} / \mathrm{C} \\
\mathrm{i}\end{array}$ & $\mathrm{mrem} / \mathrm{g}$ & $\mathrm{mrem} / \mathrm{C}$ & $\begin{array}{l}\text { mrem/ } \\
\mathrm{g}\end{array}$ & $\underset{\mathrm{i}}{\mathrm{mrem} / \mathrm{C}}$ & $\begin{array}{l}\text { mrem/ } \\
\mathrm{g}\end{array}$ & $\mathrm{mrem} / \mathrm{C}$ & $\begin{array}{l}\text { mrem/ } \\
\mathrm{g}\end{array}$ \\
\hline Pu-238 & $8.55 \mathrm{E}-03$ & 180 & 1.54 & 1400 & 11.97 & 130 & 1.11 & 55 & 0.47 & 46 & 0.39 \\
\hline Pu-239 & $5.78 \mathrm{E}-02$ & 200 & 11.55 & 1500 & 86.63 & 140 & 8.09 & 60 & 3.47 & 50 & 2.89 \\
\hline Pu-240 & $1.38 \mathrm{E}-02$ & 200 & 2.77 & 1500 & 20.77 & 140 & 1.94 & 60 & 0.83 & 50 & 0.69 \\
\hline $\mathrm{Pu}-241$ & $0.00 \mathrm{E}+00$ & 3.1 & 0.00 & 23 & 0.00 & 2.2 & 0.00 & 0.94 & 0.00 & 0.79 & 0.00 \\
\hline $\mathrm{Pu}-242$ & 1.96E-06 & 190 & 0.00 & 1400 & 0.00 & 140 & 0.00 & 57 & 0.00 & 48 & 0.00 \\
\hline Am-241 & $2.33 E-02$ & 300 & 7.00 & 2400 & 55.98 & 220 & 5.13 & 92 & 2.15 & 77 & 1.80 \\
\hline \multirow[t]{2}{*}{ Total } & 1.03E-01 & & 22.86 & & 175.35 & & 16.27 & & 6.91 & & 5.77 \\
\hline & & \multicolumn{2}{|c|}{$221 \mathrm{mrem} / \mathrm{ci} \alpha$} & \multicolumn{2}{|c|}{$1695 \mathrm{mrem} / \mathrm{ci} \alpha$} & \multicolumn{2}{|c|}{157 mrem/ci $\alpha$} & \multicolumn{2}{|c|}{$67 \mathrm{mrem} / \mathrm{ci} \alpha$} & \multicolumn{2}{|c|}{$56 \mathrm{mrem} / \mathrm{ci} \mathrm{a}$} \\
\hline \multicolumn{2}{|c|}{$12 \%$ Pu mix } & & & & & & & & & & \\
\hline Pu-238 & 1.71E-02 & 180 & 3.08 & 1400 & 23.94 & 130 & 2.22 & 55 & 0.94 & 46 & 0.79 \\
\hline Pu-239 & $5.24 \mathrm{E}-02$ & 200 & 10.48 & 1500 & 78.62 & 140 & 7.34 & 60 & 3.14 & 50 & 2.62 \\
\hline Pu-240 & $2.81 \mathrm{E}-02$ & 200 & 5.63 & 1500 & 42.22 & 140 & 3.94 & 60 & 1.69 & 50 & 1.41 \\
\hline $\mathrm{Pu}-241$ & $0.00 \mathrm{E}+00$ & 3.1 & 0.00 & 23 & 0.00 & 2.2 & 0.00 & 0.94 & 0.00 & 0.79 & 0.00 \\
\hline Pu-242 & 3.92E-06 & 190 & 0.00 & 1400 & 0.01 & 140 & 0.00 & 57 & 0.00 & 48 & 0.00 \\
\hline Am-241 & 8.75E-02 & 300 & 26.24 & 2400 & 209.92 & 220 & 19.24 & 92 & 8.05 & 77 & 6.73 \\
\hline Total & 1.85E-01 & & 45.43 & & 354.70 & & 32.74 & & 13.82 & & 11.55 \\
\hline & & \multicolumn{2}{|c|}{245 mrem/ci $\alpha$} & \multicolumn{2}{|c|}{$1916 \mathrm{mrem} / \mathrm{ci} \alpha$} & \multicolumn{2}{|c|}{177 mrem/ci $\alpha$} & \multicolumn{2}{|c|}{75 mrem/ci $\alpha$} & \multicolumn{2}{|c|}{$62 \mathrm{mrem} / \mathrm{ci} \alpha$} \\
\hline \multicolumn{2}{|c|}{$24 \%$ Pu mix } & & & & & & & & & & \\
\hline Pu-238 & 3.08E-01 & 180 & 55.40 & 1400 & 430.92 & 130 & 40.01 & 55 & 16.93 & 46 & 14.16 \\
\hline Pu-239 & 3.37E-02 & 200 & 6.73 & 1500 & 50.49 & 140 & 4.71 & 60 & 2.02 & 50 & 1.68 \\
\hline Pu-240 & 5.40E-02 & 200 & 10.81 & 1500 & 81.04 & 140 & 7.56 & 60 & 3.24 & 50 & 2.70 \\
\hline Pu-241 & $0.00 \mathrm{E}+00$ & 3.1 & 0.00 & 23 & 0.00 & 2.2 & 0.00 & 0.94 & 0.00 & 0.79 & 0.00 \\
\hline Pu-242 & $2.51 \mathrm{E}-04$ & 190 & 0.05 & 1400 & 0.35 & 140 & 0.04 & 57 & 0.01 & 48 & 0.01 \\
\hline Am-241 & $3.94 \mathrm{E}-01$ & 300 & 118.08 & 2400 & 944.62 & 220 & 86.59 & 92 & 36.21 & 77 & 30.31 \\
\hline Total & 7.89E-01 & & 191.07 & & $\begin{array}{r}1507.4 \\
2 \\
\end{array}$ & & 138.92 & & 58.41 & & 48.86 \\
\hline & & \multicolumn{2}{|c|}{$242 \mathrm{mrem} / \mathrm{ci} \alpha$} & \multicolumn{2}{|c|}{$1910 \mathrm{mrem} / \mathrm{ci} \alpha$} & \multicolumn{2}{|c|}{176 mrem/ci $\alpha$} & \multicolumn{2}{|c|}{$74 \mathrm{mrem} / \mathrm{ci} \alpha$} & \multicolumn{2}{|c|}{$62 \mathrm{mrem} / \mathrm{ci} \alpha$} \\
\hline
\end{tabular}


Table A.6. Summary of Unit Doses for Pu Blends (Units are mrem/Ci $\alpha$ )

\begin{tabular}{|c|l|r|r|r|r|r|}
\hline & & \multicolumn{1}{l|}{ offsite } & \multicolumn{1}{l|}{ onsite } & \multicolumn{1}{l|}{ offsite } & offsite & offsite \\
\hline & Ci $\alpha / \mathrm{g}$ & $<40 \mathrm{~m} \mathrm{E}$ & $<40 \mathrm{~m}$ & $<40 \mathrm{~m} \mathrm{~W}$ & $>40 \mathrm{~m} \mathrm{E}$ & $>40 \mathrm{~m} \mathrm{~W}$ \\
\hline $\mathrm{Pu}(6 \%)$ & $1.03 \mathrm{E}-01$ & 221 & 1695 & 157 & 67 & 56 \\
\hline $\mathrm{Pu}(12 \%)$ & $1.85 \mathrm{E}-01$ & 245 & 1916 & 177 & 75 & 62 \\
\hline $\mathrm{Pu}(24 \%)$ & $7.89 \mathrm{E}-01$ & 242 & 1910 & 176 & 74 & 62 \\
\hline
\end{tabular}

References:

Alexander, RE. 1974. Applications of Bioassay of Uranium. WASH 1251, U. S. Nuclear Regulatory Commission, Washington, DC.

ANSI N317-1980 (Reaffirmed 1991), Performance Criteria for Instrumentation Used for Inplant Plutonium Monitoring. American National Standards Institute, New York.

Ballinger, MY, and RB Hall. 1991. A History of Major Hanford Facilities and Processes Involving Radioactive Material. PNL-6964 HEDR, Pacific Northwest Laboratory, Richland, Washington.

Rokkan, DJ, K Rhoads, and LH Staven. 2002. Calculating Potential-to-Emit Releases and Doses for FEMPs and NOCs. HNF-3602, Revision 1, Fluor Hanford, Richland, Washington.

Shleien, B, LA Slaback, Jr., and BK Birky. 1998. Handbook of Health Physics and Radiological Health, Third Edition, Lippincott Williams \& Wilkins, New York, New York.

Sula, MJ, EH Carbaugh, and DE Bihl. 1991. Technical Basis for Internal Dosimetry at Hanford. PNL-6866, Rev. 1, Pacific Northwest Laboratory, Richland Washington. 


\section{Appendix B}

\section{Radionuclide Inventory Database Features}

The information obtained from the nuclear materials inventory, composite radioactive materials inventory, and facility management radioactive materials inventory is maintained by Effluent Management (EM) in a database. The inventory information obtained and stored in the database is described in Section 2.1.

\section{Database Population}

The nuclear materials and composite radioactive materials inventories currently are obtained in electronic formats. The general format of the electronic files is manipulated to allow electronic downloading of the information from these two sources into database tables.

The facility management radioactive materials inventory is obtained from individual research personnel who act as custodians of the material. This inventory data is provided in various forms, including handwritten documents, electronic files, and e-mail messages. Electronic files are re-formatted to the database table format and downloaded directly into the database tables. Handwritten and e-mail information is manually input to the database tables by EM personnel. For accuracy, database entries are independently verified by other EM personnel.

The information entered into the database includes the:

- Name of the staff member acting as custodian of the material

- Name of the research or support division of the custodian

- Material form - gas, liquid, powder, solid, contained, or exempt/sealed DOT

- Inventory basis - physical inventory records, estimated through process knowledge, estimated through transportation records, or estimated through other means (such as, procedures and documents)

- Nuclides

- Inventory in activity (Ci) or mass (grams) for each nuclide or plutonium/uranium blend

- Building/room in which material is stored or used

- Identification number - numbers previously assigned by the custodian or by other databases (sealed source or material balance area identification numbers)

- Comments - any additional comments related to the material (for example, reference numbers on the material, whether or not the material is considered throughput, a description of the material).

The database assigns an identification number to each entry. For sealed source and Material Balance Area (MBA) data, the identification number previously assigned to the material is used. For research inventories, the database applies a sequential number to each entry. The database assigns the following designations to the identification number: 
$\mathrm{D}$ - = Input provided by the research division

$\mathrm{G}-=$ Government sealed source

$\mathrm{P}$ - = Private radioactive material inventory (Non-DOE radioactive material under the State of Washington Radioactive Material License)

$\mathrm{M}$ - = Nuclear materials inventory.

\section{Other Database Tables}

Other database tables are used to store specific information about individual nuclides that are used in the NESHAP dose calculations:

Factors Table - Factors for the dose per curie $(\mathrm{mrem} / \mathrm{Ci})$ for different isotopes are listed in HNF-3602, Revision 1 and are entered as a separate table in the database.

Release Fraction Table - The release fractions for material forms (such as, solids, liquids, or powders) are listed in Table 2.

\section{Calculations}

The database uses queries and macros that are applied to the inventory data to calculate the potential dose for the different PNNL facilities.

Normalizing Inventory Data -- The database is designed to convert the reported mass and activity inventory units (such as, grams, $\mathrm{mCi}, \mu \mathrm{Ci}, \mathrm{mg}, \mu \mathrm{g}$ ) to curie (Ci) units for use in subsequent calculations.

Potential Dose Calculations -- Potential dose calculations are determined on a facility-specific basis. The reported inventory is first converted to $\mathrm{Ci}$ and then is multiplied by the dose factor $(\mathrm{mrem} / \mathrm{Ci})$ for the specific nuclide, the location modification factor, and the release fraction to determine the potential dose for that nuclide inventory.

Example: Calculate the potential-to-emit to the offisite maximum public receptor for $20 \mathrm{~kg}$ of depleted uranium metal ingots in the $306 \mathrm{~W}$ Building

$20 \mathrm{~kg} * 1000 \mathrm{~g} / \mathrm{kg} * 3.64 \mathrm{E}-7 \mathrm{Ci} / \mathrm{g} \mathrm{U}(\mathrm{dep}) * 1 \mathrm{E}-06 * 71 \mathrm{mrem} / \mathrm{Ci} / \mathrm{yr} * 1.0$

$=5.2 \mathrm{E}-07 \mathrm{mrem} / \mathrm{yr}$

Where : $\quad 20 \mathrm{~kg}$ is the quantity of material $1000 \mathrm{~g} / \mathrm{kg}$ is the conversion factor

3.64E-7 Ci/g is the specific activity for depleted uranium

$1 \mathrm{E}-06$ is the release fraction for solids

$71 \mathrm{mrem} / \mathrm{Ci} / \mathrm{yr}$ is the dose factor for U-235 for the offsite receptor in the east sector of the 300 Area with a $<40 \mathrm{~m}$ release height.

$1.0=$ location modification factor (with relation to 300 Area). 
The cumulative potential-to-emit for the facility is determined by summing the potential doses of each inventory entry.

\section{Reports}

Three reports are generated using the database for the NESHAP assessment as part of the final packet:

- The first is a report of the raw data provided by the research personnel, the nuclear materials inventory, and the composite radioactive materials inventory.

- The second is a summary page listing the potential dose $(\mathrm{mrem} / \mathrm{Ci})$ of the facility inventory and sign-off blocks for the preparer, reviewer, facility safety representative, divisional representative(s), and the building manager.

- The third report is a listing of each radioisotope present in the building and the associated radioisotope dose contribution in mrem and the percent of the total dose for the building. 
PNNL-10855, Rev. 3

\section{Distribution}

No. of

Copies

OFFSITE

1 DOE/Office of Scientific and Technical Information

ONSITE

2 DOE Richland Operations Office

$\begin{array}{ll}\text { T. L. Adridge K8-50 } & \text { K }\end{array}$

3 Pacific Northwest National Laboratory

B. P. Atencio P7-68

M. Y. Ballinger BSRC

J. M. Barnett P7-68

D. L. Edwards P7-68

T. L. Gervais P7-68

T. M. Graham P7-75

A. S. Ikenberry P7-79

M. J. Sula SEQUIM

Dist-1 